\title{
Corrigendum: Blood brain barrier dysfunction and delayed neurological deficits in mild traumatic brain injury induced by blast shock waves
}

\author{
Ashok K. Shetty ${ }^{1,2,3}$, Vikas Mishra ${ }^{1,2,3}$, Maheedhar Kodali ${ }^{1,2,3}$ and Bharathi Hattiangady ${ }^{1,2,3}$ \\ 1 Institute for Regenerative Medicine, Texas A\&M Health Science Center College of Medicine at Scott \& White, Temple, TX, USA \\ ${ }^{2}$ Department of Molecular and Cellular Medicine, Texas A\&M Health Science Center College of Medicine, College Station, TX, USA \\ ${ }^{3}$ Research Service, Olin E. Teague Veterans Affairs Medical Center, Central Texas Veterans Health Care System, Temple, TX, USA \\ ${ }^{*}$ Correspondence: shetty@medicine.tamhsc.edu
}

Edited by:

Ramon Santos El-Bachá, Universidade Federal da Bahia, Brazil

Reviewed by:

Rubem C. A. Guedes, Universidade Federal de Pernambuco, Brazil

Keywords: blast-related brain injury, blast shock waves, blood-brain barrier leakage, chronic traumatic encephalopathy, mild traumatic brain injury, neuroinflammation, oxidative stress, vascular resistance

\section{A corrigendum on}

Blood brain barrier dysfunction and delayed neurological deficits in mild traumatic brain injury induced by blast shock waves

by Shetty, A. K., Mishra, V., Kodali, M., and Hattiangady, B. (2014). Front. Cell. Neurosci. 8:232. doi: 10.3389/fncel.2014. 00232

The following reference in "References" section:

Goldstein, N., Goldstein, R., Terterov, D., Kamensky, A. A., Kovalev, G. I., Zolotarev, Y. A., et al. (2012). Blood-brain barrier unlocked. Biochemistry (Mosc.) 77, 419-424. doi: 10.1134/s000629791 $205001 \mathrm{X}$

Should be replaced by:

Goldstein, L. E., Fisher, A. M., Tagge, C. A., Zhang, X. L., Velisek, L., Sullivan, J. A., et al. (2012). Chronic traumatic encephalopathy in blast-exposed military veterans and a blast neurotrauma mouse model. Sci. Transl. Med. 4:134ra60. doi: 10. 1126/scitranslmed.3003716

Conflict of Interest Statement: The authors declare that the research was conducted in the absence of any commercial or financial relationships that could be construed as a potential conflict of interest.
Received: 28 October 2014; accepted: 10 November 2014; published online: 26 November 2014.

Citation: Shetty AK, Mishra V, Kodali $M$ and Hattiangady B (2014) Corrigendum: Blood brain barrier dysfunction and delayed neurological deficits in mild traumatic brain injury induced by blast shock waves. Front. Cell. Neurosci. 8:404. doi: 10.3389/fncel. 2014.00404

This article was submitted to the journal Frontiers in Cellular Neuroscience.

Copyright (c) 2014 Shetty, Mishra, Kodali and Hattiangady. This is an open-access article distributed under the terms of the Creative Commons Attribution License (CC BY). The use, distribution or reproduction in other forums is permitted, provided the original author(s) or licensor are credited and that the original publication in this journal is cited, in accordance with accepted academic practice. No use, distribution or reproduction is permitted which does not comply with these terms. 